\title{
Powder Metallurgical Techniques for Fabrication of Biomaterials
}

Jaroslav Čapek ${ }^{1,2}$, Dalibor Vojtěch ${ }^{1}$

${ }^{1}$ Department of Metals and Corrosion Engineering, University of Chemistry and Technology Prague, Technická 5, 166 28 Prague 6, Czech Republic. E-mail: Jaroslav.L.Capek@gmail.com, Dalibor.Vojtech@ vscht.cz.

${ }^{2}$ Institute of Physics, Academy of Sciences of the Czech Republic (AS CR), Na Slovance 1999/2, 182 21, Prague 8, Czech Republic. E-mail: Jaroslav.L.Capek@gmail.com.

Different powder metallurgical techniques have been intensively studied as candidates of methods suitable for fabrication of metallic biomaterials intended for orthopedic applications. The main advantage of powder metallurgical products is that they contain porosity which compromises their mechanical properties closer to those of human bone and allows transport of bodily fluid and growth of ne tissue through the implant. This enhances the healing process; moreover, the pores may be also impregnated by drugs or growth factors, which are eluted during healing and support the healing process. Recently, Ti-based and Mg-based materials have been the most investigated metallic biomaterials; therefore, the powder metallurgical methods are usually studied on those materials. In this paper, the most investigated methods will be summarized and briefly described.

Keywords: Powder metallurgy, biomaterials, porosity

\section{Acknowledgments}

The authors would like to thank the Czech Science Foundation (project no. P108/12/G043) for supporting this research.

\section{References}

[1] NIINOMI, M. (2010). Metals for biomedical devices, Woodhead publishing Ltd.

[2] FROSCH, K. H., STÜRMER, K. M. (2006). Metallic biomaterials in skeletal repair, In: European Journal of Trauma, Vol. 32, No. 2, pp. 149-159.

[3] AL JABBARI, Y. S. (2014). Physico-mechanical properties and prosthodontic applications of Co-Cr dental alloys: a review of the literature, In: Journal of Advanced Prosthodontics, Vol. 6, No. 2, pp. 138-145.

[4] NASAB, M. B., HASSAN, M. R.,SAHARI, B. B. (2010). Metallic biomaterials of knee and hip - A review, In: Trends in Biomaterials and Artificial Organs, Vol. 24, No. 2, pp. 69-82.

[5] CHEN, Q.,THOUAS, G. A. (2015). Metallic implant biomaterials, In: Materials Science and Engineering: R, Vol. 87, No. 0, pp. 1-57.

[6] HANAWA, T. (2009). Materials for metallic stents, In: J Artif Organs, Vol. 12, No. 2, pp. 73-79,

[7] NAVARRO, M., MICHIARDI, A., CASTANO, O.,PLANELL, J. A. (2008). Biomaterials in orthopaedics, In: Journal of the Royal Society Interface, Vol. 5, No. 27, pp. 1137-1158.

[8] NIINOMI, M. (2008). Metallic biomaterials, In: Journal of Artificial Organs, Vol. 11, No. 3, pp. 105-110.

[9] SANCHEZ, A. H. M., LUTHRINGER, B. J. C., FEYERABEND, F., WILLUMEIT, R. (2015). Mg and Mg alloys: How comparable are in vitro and in vivo corrosion rates? A review, In: Acta Biomaterialia, Vol. 13, No. 0, pp. 1631.

[10]ZHENG, Y. F., GU, X. N., WITTE, F. (2014). Biodegradable metals, In: Materials Science and Engineering: $R$, Vol. 77, No. 0, pp. 1-34.

[11]CAPEK, J., VOJTECH, D. (2014). Effect of sintering conditions on the microstructural and mechanical characteristics of porous magnesium materials prepared by powder metallurgy, In: Materials Science and Engineering: $C$, Vol. 35, No. pp. 21-28.

[12] ČAPEK, J., VOJTĚCH, D. (2014). Microstructural and mechanical characteristics of porous iron prepared by powder metallurgy, In: Materials Science and Engineering: C, Vol. 43, No. 0, pp. 494-501.

[13]CHEN, Y., XU, Z., SMITH, C.,SANKAR, J. (2014). Recent advances on the development of magnesium alloys for biodegradable implants, In: Acta Biomaterialia, Vol. 10, No. 11, pp. 4561-4573.

[14] VOJTECH, D., KUBASEK, J., SERAK, J., NOVAK, P. (2011). Mechanical and corrosion properties of newly developed biodegradable Zn-based alloys for bone fixation, In: Acta Biomaterialia, Vol. 7, No. 9, pp. 3515-3522.

[15] MA, E.,XU, J. (2009). Biodegradable alloys: The glass window of opportunities, In: Nature Materials, Vol. 8, No. 11, pp. 855-857. 
[16]HERMAWAN, H.,MANTOVANI, D. (2013). Process of prototyping coronary stents from biodegradable Fe-Mn alloys, In: Acta Biomaterialia, Vol. 9, No. 10, pp. 8585-8592.

[17]HERMAWAN, H., PURNAMA, A., DUBE, D., COUET, J.,MANTOVANI, D. (2010). Fe-Mn alloys for metallic biodegradable stents: degradation and cell viability studies, In: Acta Biomaterialia, Vol. 6, No. 5, pp. 1852-1860.

[18]KARAGEORGIOU, V., KAPLAN, D. (2005). Porosity of 3D biomaterial scaffolds and osteogenesis, In: Biomaterials, Vol. 26, No. 27, pp. 5474-5491.

[19]ALVAREZ, K.,NAKAJIMA, H. (2009). Metallic Scaffolds for Bone Regeneration, In: Materials, Vol. 2, No. 3, pp. 790-832.

[20]OTSUKI, B., TAKEMOTO, M., FUJIBAYASHI, S., NEO, M., KOKUBO, T., NAKAMURA, T. (2006). Pore throat size and connectivity determine bone and tissue ingrowth into porous implants: Three-dimensional microCT based structural analyses of porous bioactive titanium implants, In: Biomaterials, Vol. 27, No. 35, pp. 58925900.

[21]BOBYN, J. D., STACKPOOL, G. J., HACKING, S. A., TANZER, M.,KRYGIER, J. J. (1999). Characteristics of bone ingrowth and interface mechanics of a new porous tantalum biomaterial, In: Journal of Bone and Joint Surgery-British Volume, Vol. 81B, No. 5, pp. 907-914.

[22]ČAPEK, J., VOJTĚCH, D., OBORNÁ, A. (2015). Microstructural and mechanical properties of biodegradable iron foam prepared by powder metallurgy, In: Materials \& Design, Vol. 83, No. pp. 468-482.

[23]WU, S., LIU, X., YEUNG, K. W. K., LIU, C., YANG, X. (2014). Biomimetic porous scaffolds for bone tissue engineering, In: Materials Science and Engineering: R: Vol. 80, No. pp. 1-36.

[24]ZHANG, X., LI, X. W., LI, J. G.,SUN, X. D. (2014). Preparation and mechanical property of a novel 3D porous magnesium scaffold for bone tissue engineering, In: Materials Science and Engineering: C, Vol. 42, No. pp. 362367.

[25]MATASSI, F., BOTTI, A., SIRLEO, L., CARULLI, C.,INNOCENTI, M. (2013). Porous metal for orthopedics implants, In: Clinical cases in mineral and bone metabolism: the official journal of the Italian Society of Osteoporosis, Mineral Metabolism, and Skeletal Diseases, Vol. 10, No. 2, pp. 111-115.

[26]LYNDON, J. A., BOYD, B. J.,BIRBILIS, N. (2014). Metallic implant drug/device combinations for controlled drug release in orthopaedic applications, In: Journal of Controlled Release, Vol. 179, No. 0, pp. 63-75.

[27]NOVOSEL, E. C., KLEINHANS, C.,KLUGER, P. J. (2011). Vascularization is the key challenge in tissue engineering, In: Advanced Drug Delivery Reviews, Vol. 63, No. 4-5, pp. 300-311.

[28]LANGER, R.,CHASIN, M. (1990). Biodegradable polymers as drug delivery systems, Marcel Dekker, New York.

[29]WEN, C. E., MABUCHI, M., YAMADA, Y., SHIMOJIMA, K., CHINO, Y.,ASAHINA, T. (2001). Processing of biocompatible porous Ti and Mg, In: Scripta Materialia, Vol. 45, No. 10, pp. 1147-1153.

[30]ZHUANG, H., HAN, Y.,FENG, A. (2008). Preparation, mechanical properties and in vitro biodegradation of porous magnesium scaffolds, In: Materials Science and Engineering: C, Vol. 28, No. 8, pp. 1462-1466.

[31] ARIFVIANTO, B.,ZHOU, J. (2014). Fabrication of Metallic Biomedical Scaffolds with the Space Holder Method: A Review, In: Materials, Vol. 7, No. 5, pp. 3588-3622.

[32] THÜMMLER, F.,OBERACKER, R. Introduction to Powder Metallurgy, Maney Publishing for IOM3, the Institute of Materials, Minerals and Mining.

[33]ZHANG, Y. P., YUAN, B., ZENG, M. Q., CHUNG, C. Y.,ZHANG, X. P. (2007). High porosity and large pore size shape memory alloys fabricated by using pore-forming agent (NH4HCO3) and capsule-free hot isostatic pressing, In: Journal of Materials Processing Technology, Vol. 192-193, No. pp. 439-442.

[34]SPOERKE, E. D., MURRAY, N. G. D., LI, H., BRINSON, L. C., DUNAND, D. C.,STUPP, S. I. (2008). Titanium with aligned, elongated pores for orthopedic tissue engineering applications, In: Journal of Biomedical Materials Research Part A, Vol. 84A, No. 2, pp. 402-412.

[35]BOCANEGRA-BERNAL, M. H. (2004). Hot Isostatic Pressing (HIP) technology and its applications to metals and ceramics, In: Journal of Materials Science, Vol. 39, No. 21, pp. 6399-6420.

[36]KUMAR, A., BISWAS, K., BASU, B. (2015). Hydroxyapatite-titanium bulk composites for bone tissue engineering applications, In: Journal of Biomedical Materials Research Part A, Vol. 103, No. 2, pp. 791-806.

[37]DUDEK, A.,KLIMAS, M. (2015). Composites based on titanium alloy Ti-6Al-4V with an addition of inert ceramics and bioactive ceramics for medical applications fabricated by spark plasma sintering (SPS method), In: $M a$ terialwissenschaft Und Werkstofftechnik, Vol. 46, No. 3, pp. 237-247.

[38]DAOUSH, W. M. R. M., PARK, H. S., INAM, F., LIM, B. K.,HONG, S. H. (2015). Microstructural and Mechanical Characterization of Ti-12Mo-6Zr Biomaterials Fabricated by Spark Plasma Sintering, In: Metallurgical and Materials Transactions a-Physical Metallurgy and Materials Science, Vol. 46A, No. 3, pp. 1385-1393. 
[39]FOUSOVA, M., CAPEK, J., VOJTECH, D. (2014). Preparation of magnesium-zinc alloy by mechanical alloying, In: Manufacturing Technology, Vol. 14, No. 3, pp. 304-309,

[40]NOVÁK, P., POKORNÝ, P., VOJTĚCH, V., KNAISLOVÁ, A., ŠKOLÁKOVÁ, A., ČAPEK, J., KARLÍK, M., KOPEČEK, J. (2015). Formation of Ni-Ti intermetallics during reactive sintering at 500-650 ${ }^{\circ} \mathrm{C}$, In: Materials Chemistry and Physics, Vol. 155, No. 0, pp. 113-121.

[41] WHITNEY, M., CORBIN, S. F.,GORBET, R. B. (2008). Investigation of the mechanisms of reactive sintering and combustion synthesis of NiTi using differential scanning calorimetry and microstructural analysis, In: Acta Materialia, Vol. 56, No. 3, pp. 559-570.

[42]NOVAK, P., MEJZLIKOVA, L., MICHALCOVA, A., CAPEK, J., BERAN, P., VOJTECH, D. (2013). Effect of SHS conditions on microstructure of NiTi shape memory alloy, In: Intermetallics, Vol. 42, No. pp. 85-91.

[43]BASSANI, P., GIULIANI, P., TUISSI, A.,ZANOTTI, C. (2009). Thermomechanical Properties of Porous NiTi Alloy Produced by SHS, In: Journal of Materials Engineering and Performance, Vol. 18, No. 5-6, pp. 594-599.

[44]BISWAS, A. (2005). Porous NiTi by thermal explosion mode of SHS: processing, mechanism and generation of single phase microstructure, In: Acta Materialia, Vol. 53, No. 5, pp. 1415-1425.

[45] KUČERA, V., ČAPEK, J., MICHALCOVÁ, A., VOJTĚCH, D. (2014). Preparation and characterization of niti shape memory alloy preparedby powder metallurgy, In: Manufacturing Technology, Vol. 14, No. 3, pp. 342-347.

[46] WHITNEY, M., CORBIN, S. F.,GORBET, R. B. (2009). Investigation of the influence of Ni powder size on microstructural evolution and the thermal explosion combustion synthesis of NiTi, In: Intermetallics, Vol. 17, No. 11, pp. 894-906.

[47]QUADBECK, P., HAUSER, R., KÜMMEL, K., STANDKE, G., STEPHANI, G., NIES, B., RÖßLER, S., WEGENER, B. (2010). Iron based cellular metals for degradable synthetic bone replacement, In: PM2010 World Congress, Florenz, Italy, $6 \mathrm{p}$.

[48]LI, J. P., VAN BLITTERSWIJK, C. A.,DE GROOT, K. (2004). Factors having influence on the rheological properties of Ti6A14V slurry, In: Journal of Materials Science: Materials in Medicine, Vol. 15, No. 9, pp. 951-958.

[49]BANHART, J. (2001). Manufacture, characterisation and application of cellular metals and metal foams, In: Progress in Materials Science, Vol. 46, No. 6, pp. 559-632.

[50]QUADBECK, P., KÜMMEL, K., HAUSER, R., STANDKE, G., ADLER, J., STEPHANI, G.,KIEBACK, B. (2011). Structural and Material Design of Open-Cell Powder Metallurgical Foams, In: Advanced Engineering Materials, Vol. 13, No. 11, pp. 1024-1030.

[51]FONT, R., FULLANA, A., $\square$ ABALL $\square$ RO, J. A., $\square$ AND $\square$ LA, J.,GAR $\square$ ÁA, A. (2001). Pyrolysis study of polyurethane, In: Journal of Analytical and Applied Pyrolysis, Vol. 58-59, No. 0, pp. 63-77.

[52]JEE, C. S. Y., GUO, Z. X., EVANS, J. R. G.,ÖZGÜVEN, N. (2000). Preparation of high porosity metal foams, In: Metallurgical and Materials Transactions B, Vol. 31, No. 6, pp. 1345-1352.

[53]LEWIS, G. (2013). Properties of open-cell porous metals and alloys for orthopaedic applications, In: Journal of Materials Science: Materials in Medicine, Vol. 24, No. 10, pp. 2293-2325.

[54]TORRES, Y., RODRÍGUEZ, J. A., ARIAS, S., ECHEVERRY, M., ROBLEDO, S., AMIGO, V.,PAVÓN, J. J. (2012). Processing, characterization and biological testing of porous titanium obtained by space-holder technique, In: Journal of Materials Science, Vol. 47, No. 18, pp. 6565-6576.

[55]MANSOURIGHASRI, A., MUHAMAD, N.,SULONG, A. B. (2012). Processing titanium foams using tapioca starch as a space holder, In: Journal of Materials Processing Technology, Vol. 212, No. 1, pp. 83-89.

[56]WANG, X., LI, Y., XIONG, J., HODGSON, P. D.,WEN, C. e. (2009). Porous TiNbZr alloy scaffolds for biomedical applications, In: Acta Biomaterialia, Vol. 5, No. 9, pp. 3616-3624.

[57]AYDOĞMUŞ, T.,BOR, Ş. (2009). Processing of porous TiNi alloys using magnesium as space holder, In: Journal of Alloys and Compounds, Vol. 478, No. 1-2, pp. 705-710.

[58]NIU, W., BAI, C., QIU, G.,WANG, Q. (2009). Processing and properties of porous titanium using space holder technique, In: Materials Science and Engineering: A, Vol. 506, No. 1-2, pp. 148-151.

[59] KWOK, P. J., OPPENHEIMER, S. M.,DUNAND, D. C. (2008). Porous Titanium by Electro-chemical Dissolution of Steel Space-holders, In: Advanced Engineering Materials, Vol. 10, No. 9, pp. 820-825. 